\title{
Influence of Indoor Climate on Employees in Office Buildings-A Case Study
}

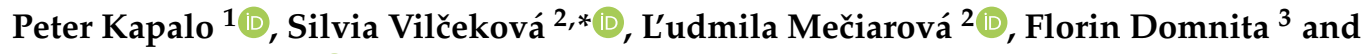 \\ Mariusz Adamski 4 (D) \\ 1 Institute of Architectural Engineering, Faculty of Civil Engineering, Technical University of Košice, \\ Vysokoškolská 4, 04200 Košice, Slovakia; peter.kapalo@tuke.sk \\ 2 Institute of Environmental Engineering, Faculty of Civil Engineering, Technical University of Košice, \\ Vysokoškolská 4, 04200 Košice, Slovakia; ludmila.meciarova@gmail.com \\ 3 Department of Building Services Engineering, Technical University of Cluj-Napoca, B-dul 21 December 1989, \\ nr. 128-130, 400604 Cluj-Napoca, Romania; florin.domnita@insta.utcluj.ro \\ 4 Faculty of Civil and Environmental Engineering, Bialystok University of Technology, Wiejska 45E street, \\ 15-351 Białystok, Poland; mariusz.adamski@pb.edu.pl \\ * Correspondence: silvia.vilcekova@tuke.sk; Tel.: +421-55-602-4260
}

Received: 16 June 2020; Accepted: 7 July 2020; Published: 10 July 2020

\begin{abstract}
The presented research work is aimed at investigation of the influence of indoor environmental conditions on employees in office buildings. Monitoring of carbon dioxide, temperature, relative humidity and pulse, as well as subjective evaluation, was carried out in three office rooms where air conditioning systems ensured the required amount of fresh air. Investigation showed that in two offices (A and B), the amount of fresh air did not comply with EN 15251:2017. The concentration of $\mathrm{CO}_{2}$ in office A was above $1000 \mathrm{ppm}$ for $72 \%$ of the total length of stay. Respondents confirmed fatigue and headaches. In offices $\mathrm{A}$ and $\mathrm{B}$, where $\mathrm{CO}_{2}$ concentration was around $1000 \mathrm{ppm}$, people with a weight of up to $70 \mathrm{~kg}$ experienced a significant increase in air temperature as well as odor. Persons with weight higher than $75 \mathrm{~kg}$ experienced a slight decrease in air quality. In office $\mathrm{C}$, where $\mathrm{CO}_{2}$ concentration was around $800 \mathrm{ppm}$, respondents reported a slight decrease in air quality. According to pulse monitoring, it can be stated that in an office where there is an insufficient supply of fresh air, the pulse of a person falls or only slightly rises. A decrease in pulses may indicate the attenuation or stunning of people caused by poor air quality.
\end{abstract}

Keywords: office building; $\mathrm{CO}_{2}$; temperature; relative humidity; pulse; questionnaire

\section{Introduction}

The main source of carbon dioxide $\left(\mathrm{CO}_{2}\right)$ in the indoor environment is human respiration [1]. Levels of $\mathrm{CO}_{2}$ are often considered as an important indicator of indoor air quality as well as ventilation intensity [2]. $\mathrm{CO}_{2}$ concentrations may vary from building to building and within one building may vary from location to location. These variations are caused by the dispersion of $\mathrm{CO}_{2}$, which varies with room conditions and variables such as internal and external environmental conditions, the occupancy level, the air flow rate etc. [3]. The mean concentrations of $\mathrm{CO}_{2}$ were ranged from 488 to $1164 \mathrm{ppm}$ in ten office buildings in Taiwan in the study of [4]. In Delhi, the mean concentrations of $\mathrm{CO}_{2}$ in two office buildings were 1513 and $1338 \mathrm{ppm}$ [5]. According to another study [6], mean $\mathrm{CO}_{2}$ concentrations were from 742 to $920 \mathrm{ppm}$ in a Slovak office building. Levels of $\mathrm{CO}_{2}$ normally occurring in the indoor environment do not represent a major risk to human health; however, higher levels were associated with some adverse effects [7]. Authors in study [8] observed a relationship between $\mathrm{CO}_{2}$ concentrations and lower respiratory and mucous membrane symptoms. The generalized estimating equation models 
in the study of [9] showed that office workers exposed to indoor $\mathrm{CO}_{2}$ levels higher than $800 \mathrm{ppm}$ were likely to report more upper respiratory symptoms and eye irritation. A well known issue in indoor environments is sick building syndrome (SBS), which is the result of exposure to indoor air pollutants or, generally speaking, exposure to poor indoor air quality. Headache, fatigue, nausea, dizziness, eye, nose and throat irritation, sensation of dry mucous membranes, skin erythema, high frequency of airway infection and cough, hoarseness, wheezing, and unspecified hypersensitivity are the symptoms of SBS [10]. In study of [11] was investigated the relationship between indoor air quality and prevalence of SBS in old and new office buildings in Selangor. The authors proposed that an increase in ventilation rates per person would significantly reduce prevalence of SBS. Authors in study of [12] in their review observed that half of the $\mathrm{CO}_{2}$ studies suggest that the risk of SBS continued to decease significantly with decreasing $\mathrm{CO}_{2}$ below $800 \mathrm{ppm}$. Researchers in study of [13] performed a multiparametric analysis on environmental factors such as temperature, relative humidity and $\mathrm{CO}_{2}$, the physiological stress reactions in the body, measured alertness and subjective symptoms during simulated office work. This study showed that high $\mathrm{CO}_{2}$ levels can caused physiological changes such as higher $\mathrm{CO}_{2}$ concentrations in tissues, increase of peripheral blood circulation during exposure to elevated $\mathrm{CO}_{2}$ levels, as well as changes in heart rate variation, and noted that these physiological effects can decrease the building user's functional ability. Thus, indoor $\mathrm{CO}_{2}$ was linked with a decrease of performance. In study of [14] was investigated the impact of different $\mathrm{CO}_{2}$ levels on airline pilots in a flight simulator and suggested that there is a direct association between $\mathrm{CO}_{2}$ levels above 1000 ppm and performance. A different study [15] showed that levels of $\mathrm{CO}_{2}$ are associated with cognitive function. Study [16] assessed direct effects of increased $\mathrm{CO}_{2}$ on decision making and found that decision-making performance in six of nine scales significantly decreased at $1000 \mathrm{ppm}$ in comparison with $600 \mathrm{ppm}$, and at $2500 \mathrm{ppm}$ large, significant reductions occurred in seven scales of decision-making performance. Results from the study of [17], in which the impact of $\mathrm{CO}_{2}$ levels on intensity of mental work and human well-being were examined, showed that the capacity to concentrate attention and human well-being decline with increasing $\mathrm{CO}_{2}$ concentration up to $3000 \mathrm{ppm}$. Sufficient ventilation intensity or proper design of the air distribution systems (diffusers) will help to create a healthy indoor environment [18]. Studies [19,20] investigated that by reorganizing the rooms in the workplace to achieve a combination of sedentary activity with physical activity, it is possible to improve the perceived indoor environmental quality. Results of the study [19] showed that the availability of space which allows people to occupy a workstation and use it as a proprietary desk, and the feeling of working in a traditional open plan layout are important features in the workplace. According this study, $44 \%$ of interviewees answered the questionnaire saying that they would appreciate the possibility to personalize their desk to feel more comfortable at work. In the study [20], the research task was focused on job satisfaction, environmental satisfaction and perceived support in the work environments. Results pointed to slightly higher average job satisfaction than environmental satisfaction and perceived support in the work environment. Further, environmental satisfaction and perceived support in the work environment were highly correlated with each other. This study also recommended an effective layout design of a sustainable building, taking into account the possible positive and/or negative impacts of active design on organization performance for better implementation outcomes. In addition to these aspects, indoor air factors also need to be investigated. As can be seen, despite the fact that $\mathrm{CO}_{2}$ is not an indoor air pollutant of greatest concern, at high levels it has a significant influence on humans. Therefore, the aim of this study is the investigation of dynamic changes of indoor air factors in offices and their influence on employees during working shifts. An innovative approach can be considered the investigation of the relationship between indoor air parameters, the human pulse and the subjective perception of employees. 


\section{Materials and Methods}

\subsection{Site Description}

An eight story office building located in Košice, Slovakia, was selected for the investigation of indoor environments and their impact on employees who carried out administrative work on personal computers. Experimental measurements were performed in three office rooms in January with outdoor air temperature ranging from -2 to $0{ }^{\circ} \mathrm{C}$. It is important to note that the envelope of the building consisted of $90 \%$ of the transparent area and $10 \%$ of the non-transparent area.

The size and shape of the offices were different and the workplaces were arranged differently. Respondents were present during the measurements for the time of $8 \mathrm{~h}$. Table 1 presents basic information about the offices.

Table 1. Basic information about monitored offices.

\begin{tabular}{ccccccc}
\hline Room & $\begin{array}{c}\text { Floor Area } \\
\left(\mathbf{m}^{\mathbf{2}}\right)\end{array}$ & $\begin{array}{c}\text { Volume of Room } \\
\left(\mathbf{m}^{\mathbf{3}} \mathbf{)}\right.\end{array}$ & $\begin{array}{c}\text { Number of Men } \\
(-\mathbf{)}\end{array}$ & $\begin{array}{c}\text { Number of Women } \\
(\mathbf{-})\end{array}$ & $\begin{array}{c}\text { Volume of Room } \\
\left(\mathbf{m}^{\mathbf{3}} / \text { Person) }\right.\end{array}$ & $\begin{array}{c}\text { Volumetric Air Flow Rate } \\
\left(\mathbf{m}^{\mathbf{3}} /(\mathbf{h} . \text { Person) }\right.\end{array}$ \\
\hline A & 60.00 & 156.00 & 4 & 5 & 17.33 & 19.4 \\
B & 73.90 & 206.92 & 10 & 1 & 18.81 & 40.5 \\
C & 86.00 & 223.60 & 9 & 2 & 20.33 & 47.8 \\
\hline
\end{tabular}

Office A was occupied by 9 employees with average age of 37 years and average weight of $69 \mathrm{~kg}$. Five of them were women aged from 25 to 44 years with weight of 50-66 kg; and 4 were men aged 33 to 41 weighing from 67 to $90 \mathrm{~kg}$. In office B were present 11 people, whose average age was 36 years and average weight $84 \mathrm{~kg}$. One woman was aged 57 years with weight of $65 \mathrm{~kg}$ and 10 men aged 25 to 42 weighed 55 to $110 \mathrm{~kg}$. Office C was occupied by 11 employees with average age of 28 years and average weight of $80 \mathrm{~kg}$, of which 2 were women 25 years old with weight from 50 to $68 \mathrm{~kg}$ and 9 were men aged 25-38 with weight between 75 and $112 \mathrm{~kg}$.

Mechanical rooms for air-conditioning were placed on each floor and the required amount of fresh air was adjusted by demand. Indoor air quality in office spaces was ensured through combined air and water conditioning systems. The air system provided fresh air to the room. The two-water pipe fan coil system with windscreen fan coils ensured the required room temperature.

Volumetric flow rate of inlet air and exhaust air was determined. Measurement of volumetric air flow rate was carried out by the Testo 480 anemometer, which measured flow rate of the incoming air in the air supply duct before the end element. The volumetric air flow rate was calculated on the basis of the measured air flow rate and internal cross-section of air-conditioning pipe. Air flow rate measurement was performed at a time when the air-conditioning unit was operating at $100 \%$ power. The volumetric flow rates of the intake air are shown in Table 1.

\subsection{Objective Measurement}

$\mathrm{CO}_{2}$ concentration, indoor air temperature, relative air humidity and human pulse were measured in all three office rooms in which employees performed sedentary office work.

A Testo 480 instrument with Testo 0635 air flow sensor was used to measure the air flow rate. The measuring range of the instrument is from $0 \mathrm{~m} / \mathrm{s}$ to $+20 \mathrm{~m} / \mathrm{s}$, the instrument's sensitivity is $0.01 \mathrm{~m} / \mathrm{s}$ and the accuracy is $\pm 0.03 \mathrm{~m} / \mathrm{s}$. For measuring the $\mathrm{CO}_{2}$ concentration, indoor air temperature and relative humidity, we used the Testo 435-4 instrument with Testo 0632 sensor. The measuring range of the instrument for temperature is from 0 to $+50{ }^{\circ} \mathrm{C}$, the instrument's sensitivity is $0.1{ }^{\circ} \mathrm{C}$ and the accuracy is $\pm 0.3^{\circ} \mathrm{C}$. The measuring range of the instrument for relative humidity is from $0 \%$ to $100 \%$, the instrument's sensitivity is $0.1 \mathrm{RH}$ and the accuracy is $\pm 1.8 \mathrm{RH}$. The measuring range of the instrument for $\mathrm{CO}_{2}$ concentration is from 0 to $10,000 \mathrm{ppm}$, the instrument's sensitivity is 1 ppm and the accuracy is $\pm 3 \%$. The operative temperature of the measuring device is between -20 and $+50{ }^{\circ} \mathrm{C}$. The instruments were placed in the middle of the room at a height of $1 \mathrm{~m}$. 
The Sanitas-SBM 42 was used to measure the human pulse. The measuring range of this device is from 30 to 180 pulses/min, its sensitivity is 1 pulse and the accuracy of the instrument is $\pm 5 \%$. The operating temperature of the instrument is from -10 to $+40{ }^{\circ} \mathrm{C}$.

\subsection{Subjective Evaluation}

During the experimental measurement, the persons in the room performed subjective evaluation of the indoor environment through the questionnaires focused on gender, age, weight, sensation of room temperature, odor and overall air condition. Questionnaires were filled out at the beginning and at the end of the working shift.

\section{Results and Discussion}

Table 2 presents minimum, maximum and mean values of indoor air temperature, relative humidity and $\mathrm{CO}_{2}$ concentrations during the total time of monitoring.

Table 2. Indoor air parameters.

\begin{tabular}{|c|c|c|c|c|c|c|c|c|c|}
\hline \multirow[t]{2}{*}{ Office } & \multicolumn{3}{|c|}{$\begin{array}{c}\text { Indoor Air Temperature } \\
{\left[{ }^{\circ} \mathrm{C}\right]}\end{array}$} & \multicolumn{3}{|c|}{$\begin{array}{c}\text { Relative Humidity } \\
{[\%]}\end{array}$} & \multicolumn{3}{|c|}{$\begin{array}{c}\mathrm{CO}_{2} \text { Concentration } \\
{[\mathrm{ppm}]}\end{array}$} \\
\hline & Min. & Max. & Mean & Min. & Max. & Mean & Min. & Max. & Mean \\
\hline A & 22.9 & 25.0 & 24.5 & 20.1 & 26.4 & 23.9 & 374 & 1162 & 863 \\
\hline B & 22.8 & 25.5 & 24.5 & 17.7 & 25.8 & 22.8 & 379 & 1006 & 702 \\
\hline C & 22.2 & 25.3 & 22.4 & 19.6 & 23.7 & 21.6 & 396 & 869 & 651 \\
\hline
\end{tabular}

\subsection{Office A}

The measured volumetric flow rate of supplied fresh air was $19.4 \mathrm{~m}^{3} / \mathrm{h}$ per person in office A. This amount of fresh air does not comply with EN 15251 [21], which prescribes $42 \mathrm{~m}^{3} / \mathrm{h}$ per person for II. category (standard level for new and reconstructed buildings) and for the given room type. Figure 1 depicts levels of $\mathrm{CO}_{2}$ concentration, indoor air temperature and relative humidity.

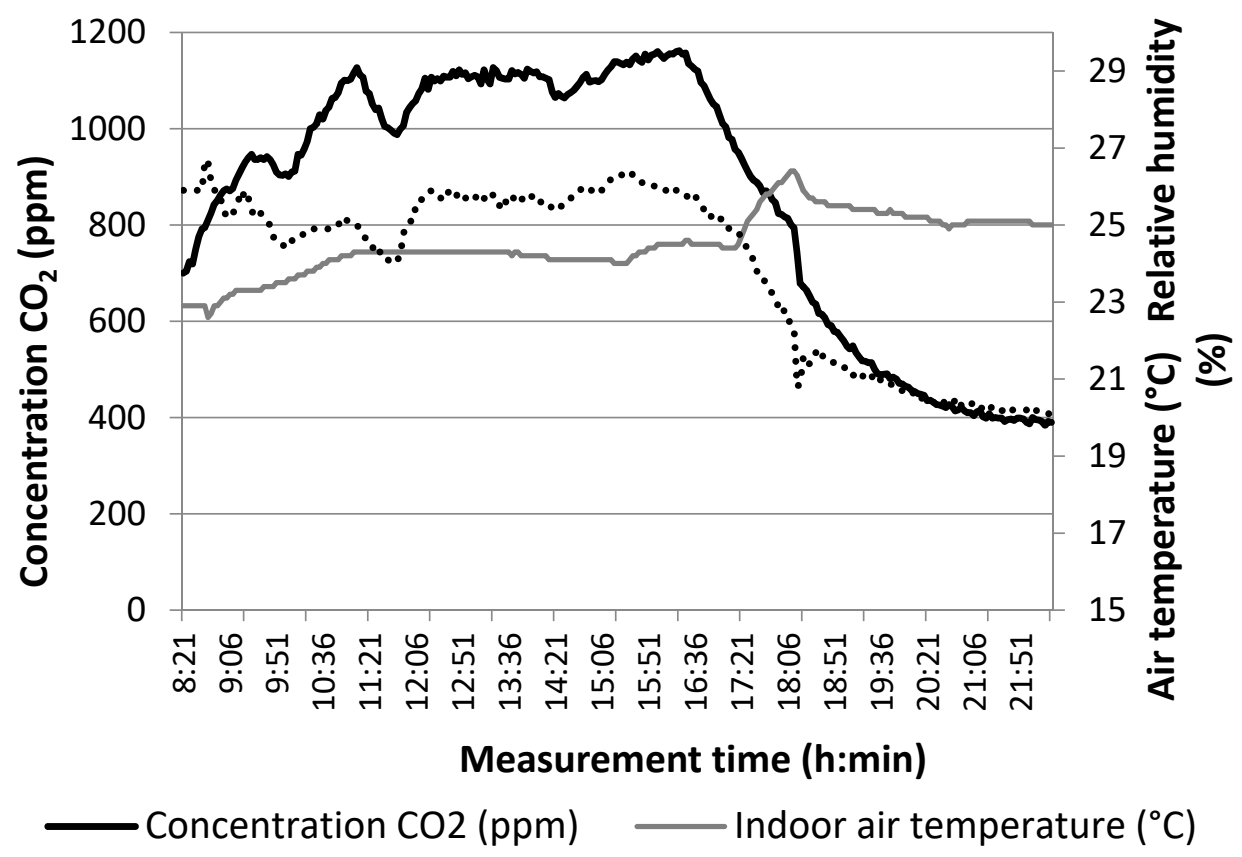

Figure 1. Indoor air parameters in office A.

Respondents stayed in the office from 9.00 a.m. to 5.00 p.m. During their work the values of $\mathrm{CO}_{2}$ concentration, indoor air temperature and relative humidity ranged from 871 to $1162 \mathrm{ppm}$, from 23.1 
to $24.6^{\circ} \mathrm{C}$ and from $24.0 \%$ to $26.4 \%$, respectively. Mean values were $1065 \mathrm{ppm}$ for $\mathrm{CO}_{2}$ concentration, $24.1^{\circ} \mathrm{C}$ for indoor air temperature and $25.4 \%$ for relative humidity.

From Figure 1, we can see that the $\mathrm{CO}_{2}$ concentration in office A was greater than $1000 \mathrm{ppm}$ for $345 \mathrm{~min}$, which was $72 \%$ of the total occupancy time $(480 \mathrm{~min})$. The highest measured $\mathrm{CO}_{2}$ concentration was $1162 \mathrm{ppm}$. It is necessary to say that employees felt a lack of fresh air during the experimental measurement.

\subsection{Office $B$}

Measured volumetric flow rate of supplied fresh air was $40.5 \mathrm{~m}^{3} / \mathrm{h}$ per person in office B. This amount of fresh air does not comply with EN 16798-1, which prescribes $42.13 \mathrm{~m}^{3} / \mathrm{h}$ per person for the given room type. Figure 2 depicts the variation of $\mathrm{CO}_{2}$ concentration, indoor air temperature and relative humidity with measurement time. Respondents stayed in the office from $9.00 \mathrm{a} . \mathrm{m}$. to 5.00 p.m. During their work, the values of $\mathrm{CO}_{2}$ concentration, indoor air temperature and relative humidity ranged from 696 to $1006 \mathrm{ppm}$, from 23.7 to $25.5^{\circ} \mathrm{C}$ and from $22.4 \%$ to $25.8 \%$, respectively. Mean values were $882 \mathrm{ppm}$ for $\mathrm{CO}_{2}$ concentration, $24.9^{\circ} \mathrm{C}$ for indoor air temperature and $24.2 \%$ for relative humidity. During the experimental measurement, staff did not feel a significant decrease in air quality. $\mathrm{CO}_{2}$ concentration in office $\mathrm{B}$ was greater than $1000 \mathrm{ppm}$ for $9 \mathrm{~min}$, which was $2 \%$ of the total time spent by employees. The peak $\mathrm{CO}_{2}$ concentration was $1006 \mathrm{ppm}$.

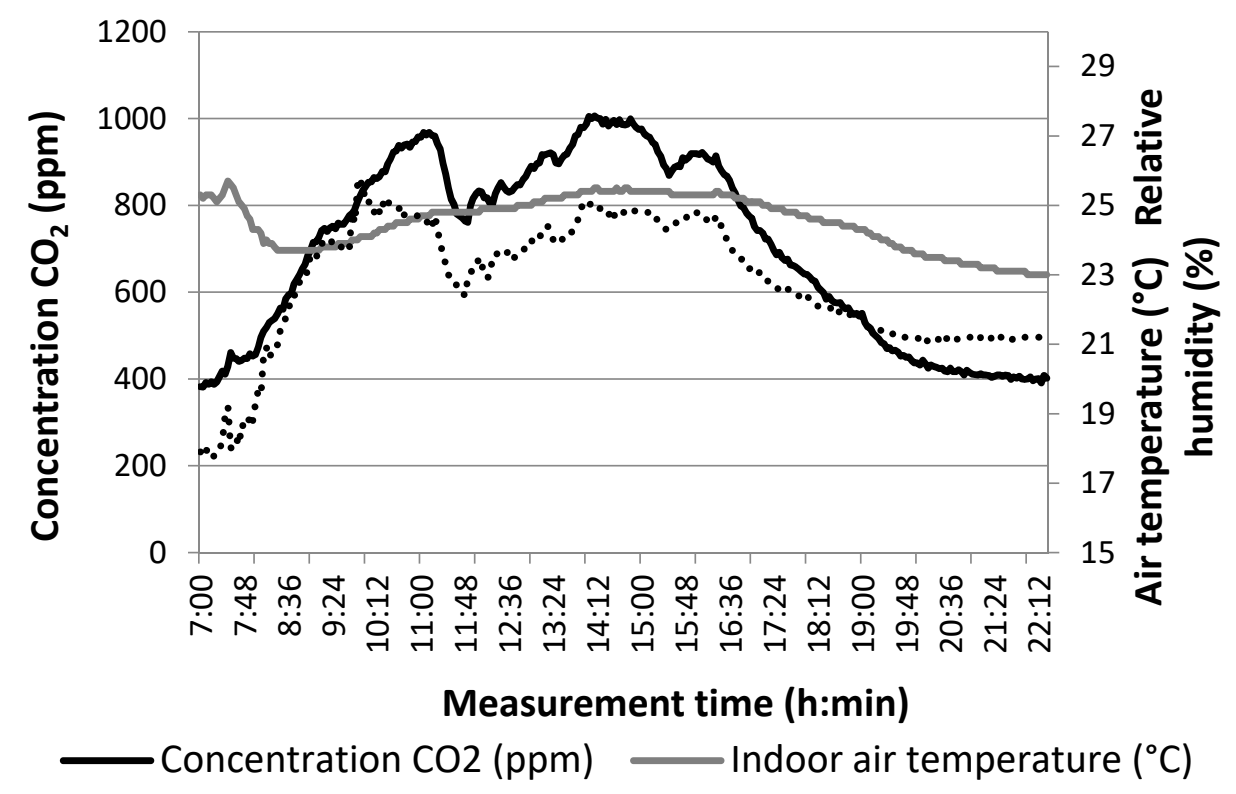

Figure 2. Indoor air parameters in office B.

\subsection{Office $C$}

In office C, measured volumetric supplied air flow rate was $47.8 \mathrm{~m}^{3} / \mathrm{h}$ per person. This amount of air complies with EN 16798-1, which prescribes $44.90 \mathrm{~m}^{3} / \mathrm{h}$ per person for the given room type. Figure 3 illustrates the variation of $\mathrm{CO}_{2}$ concentration, indoor air temperature and relative humidity with measurement time. Respondents stayed in office from 8.45 a.m. to 4.45 p.m. During their work, the values of $\mathrm{CO}_{2}$ concentration, indoor air temperature and relative humidity ranged from 689 to $869 \mathrm{ppm}$, from 23.6 to $25.3^{\circ} \mathrm{C}$ and from $20.9 \%$ to $23.5 \%$, respectively. Mean values were $783 \mathrm{ppm}$ for $\mathrm{CO}_{2}$ concentration, $24.9^{\circ} \mathrm{C}$ for indoor air temperature and $22.5 \%$ for relative humidity. During the experimental measurement, the employees did not feel a significant decrease in air quality. 


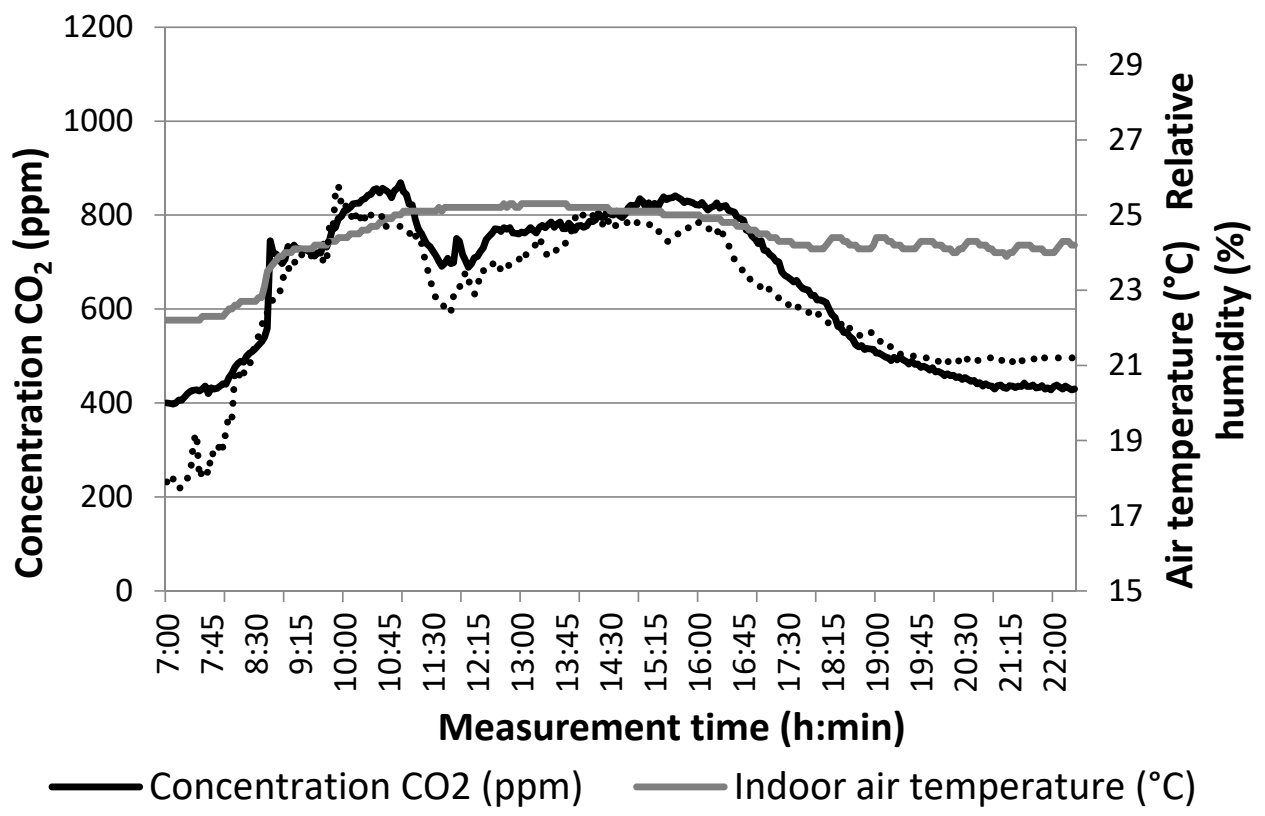

Figure 3. Indoor air parameters in office C.

Figure 3 shows that $\mathrm{CO}_{2}$ concentration did not exceed the value of $1000 \mathrm{ppm}$. From the indoor air parameters, it can be stated that the indoor air temperature was relatively high but still acceptable. Outdoor air temperature and sun's intensity ranged from -2 to $0^{\circ} \mathrm{C}$ and from 40 to $100 \mathrm{~W} / \mathrm{m}^{2}$, respectively. As the envelope of the building was predominantly glazed, the interior was overheated by sunlight. In all three offices, the relative humidity values were below the permissible minimum, which makes it possible to conclude that air conditioning did not provide air humidification.

Room A, where 9 people worked, had the smallest floor area as well as air volume per person. The volumetric flow rate of fresh air supplied per person was $19.4 \mathrm{~m}^{3} / \mathrm{h}$, which absolutely does not meet the hygienic minimum. Rooms B and C, where 11 people worked in each office, had a larger floor area as well as volume of air per person than room A. The volumes of fresh air of $40.5 \mathrm{~m}^{3} / \mathrm{h}$ per person (office B) and $47.8 \mathrm{~m}^{3} / \mathrm{h}$ per person (office C) met the hygienic requirement.

The concentration of carbon dioxide in office A was above $1000 \mathrm{ppm}$ for $72 \%$ of the total length of stay. Although this is not a large increase in carbon dioxide, it can be said that the environment was inadequate.

\subsection{Human Pulse}

During the working shift, pulse measurements of the respondents were performed. The pulse measurement was done a few minutes after the employees arrived in the office room to calm them down. Next pulse measurements were performed before people left for a lunch break, after a lunch break and before leaving the workplace at the end of the shift. Table 3 presents the recorded pulses of the respondents.

From Table 3, where the individual pulses were recorded, it was observed that pulses were dropping in all persons during the morning worked in office A. Pulses dropped in $82 \%$ and $55 \%$ of the total number of people in offices B and C, respectively. After a lunch break in all three offices, pulses were mostly elevated, which can be explained by the walk they had to take to the restaurant. For people who were not out of the room during the lunch break and resting in the room, pulses continued to fall slightly. During the afternoon, pulses sharply declined in $44 \%$ of the total number of people who worked in office A. Among others, pulses increased only slightly. In office B, pulses dropped in $36 \%$ of the total number of people, but less than those in office A. In office C, pulse dropped in $82 \%$ of the total number of people but also less than those in room A. From pulse levels, it can be stated that in an office where there is an insufficient supply of fresh air, the pulse of a person falls or only 
slightly rises. A decrease in pulses may indicate the attenuation or stunning of people caused by poor air quality. In the afternoon, when the $\mathrm{CO}_{2}$ concentration was above $1000 \mathrm{ppm}$, the pulse drop was more pronounced, especially for those with a higher weight. In rooms where there was the required fresh air supply, the pulses fluctuated.

Table 3. Heart-beat intensity (pulse) of occupants in offices.

\begin{tabular}{|c|c|c|c|c|c|c|c|}
\hline \multirow{2}{*}{ Office } & \multirow{2}{*}{ Sex } & \multirow{2}{*}{$\begin{array}{l}\text { Weight of } \\
\text { Person [kg] }\end{array}$} & \multicolumn{4}{|c|}{ Heart-Beat Intensity (Pulse) of Occupants in Offices [pulse/min] } & \multirow{2}{*}{$\begin{array}{c}\text { Increase/Decrease } \\
\text { of Pulse [\%] }\end{array}$} \\
\hline & & & $\begin{array}{c}\text { Coming into } \\
\text { the Office }\end{array}$ & $\begin{array}{l}\text { Departure for } \\
\text { Lunch }\end{array}$ & $\begin{array}{c}\text { Return from } \\
\text { Lunch }\end{array}$ & $\begin{array}{l}\text { Departure from } \\
\text { the Office }\end{array}$ & \\
\hline \multirow{9}{*}{ A } & Woman & 50 & 75 & 74 & 76 & 77 & 2.67 \\
\hline & Woman & 51 & 82 & 81 & 82 & 84 & 2.44 \\
\hline & Woman & 60 & 65 & 63 & 60 & 56 & -13.85 \\
\hline & Woman & 66 & 69 & 62 & 62 & 77 & 11.59 \\
\hline & Woman & 66 & 64 & 63 & 70 & 65 & 1.56 \\
\hline & Man & 67 & 70 & 71 & 71 & 72 & 2.86 \\
\hline & Man & 85 & 96 & 90 & 107 & 76 & -20.83 \\
\hline & Man & 87 & 63 & 71 & 72 & 60 & -4.76 \\
\hline & Man & 90 & 87 & 66 & 92 & 63 & -27.59 \\
\hline \multirow{11}{*}{ B } & Man & 55 & 78 & 55 & 64 & 57 & -26.92 \\
\hline & Woman & 65 & 68 & 71 & 69 & 90 & 32.35 \\
\hline & Man & 80 & 67 & 62 & 75 & 65 & -2.99 \\
\hline & Man & 80 & 57 & 57 & 61 & 61 & 7.02 \\
\hline & Man & 83 & 98 & 95 & 93 & 84 & -14.29 \\
\hline & Man & 85 & 65 & 53 & 60 & 55 & -15.38 \\
\hline & Man & 86 & 76 & 76 & 94 & 108 & 42.11 \\
\hline & Man & 90 & 65 & 60 & 58 & 63 & -3.08 \\
\hline & Man & 93 & 60 & 66 & 54 & 56 & -6.67 \\
\hline & Man & 97 & 87 & 85 & 84 & 86 & -1.15 \\
\hline & Man & 110 & 95 & 86 & 84 & 87 & -8.42 \\
\hline \multirow{11}{*}{ C } & Woman & 50 & 72 & 73 & 80 & 70 & -2.78 \\
\hline & Woman & 68 & 64 & 70 & 77 & 72 & 12.50 \\
\hline & Man & 75 & 72 & 66 & 75 & 61 & -15.28 \\
\hline & Man & 76 & 80 & 88 & 75 & 65 & -18.75 \\
\hline & Man & 80 & 78 & 60 & 74 & 62 & -20.51 \\
\hline & Man & 80 & 75 & 69 & 91 & 88 & 17.33 \\
\hline & Man & 81 & 60 & 67 & 78 & 66 & 10.00 \\
\hline & Man & 86 & 76 & 88 & 79 & 86 & 13.16 \\
\hline & Man & 87 & 98 & 93 & 96 & 96 & -2.04 \\
\hline & Man & 90 & 85 & 66 & 74 & 63 & -25.88 \\
\hline & Man & 112 & 72 & 71 & 98 & 82 & 13.89 \\
\hline
\end{tabular}

\subsection{Subjective Evaluation}

Subjective evaluation of the indoor environment through the questionnaires, which focused on indoor air temperature and odor, showed that odor proportionately increased as a by-product of the presence of people with the increase of the carbon dioxide concentration. Experimental measurement was carried out in normal workplace conditions, with as few staff as possible to perform their duties. For this reason, the questions were simple and concise. From the point of view of the indoor air temperature, respondents could choose one of the possible answers: cold $(-2)$, slightly cold $(-1)$, neutral (0), slightly hot $(+1)$ and hot $(+2)$. The odor intensity scale was: odorless $(0)$, weak odor $(+1)$, slight odor (+2) and strong odor (+3). The results of the questionnaires are shown in Figures 4-9, with the male and female responses being shown separately.

From the subjective evaluation, we can say the air quality in all three offices got to be worse at the end of working hours. Significant air quality downgrades of up to 2 levels (from weak odor up to strong odor) were found in office $A$, where the smallest flow of fresh air was also measured. In offices $\mathrm{A}$ and $\mathrm{B}$, where the carbon dioxide concentration was around $1000 \mathrm{ppm}$, people with a weight of up to $70 \mathrm{~kg}$ experienced a significant increase in air temperature as well as odor. Persons weighing more than $75 \mathrm{~kg}$ experienced a slight decrease in air quality. In office $\mathrm{C}$, where the carbon dioxide concentration was around 800 ppm, respondents reported a slight decrease in air quality. From subjective evaluation, we can see that the quality of indoor air was getting worse during the stay of the persons in the room. Women responded to the increase in temperature and odor more than men. Respondents noted that they were extremely tired after the end of their working shift and that some of them had headaches. It can be said that workers during the day adapted to their environment, but symptoms appeared after hours spent in an unhealthy environment. 


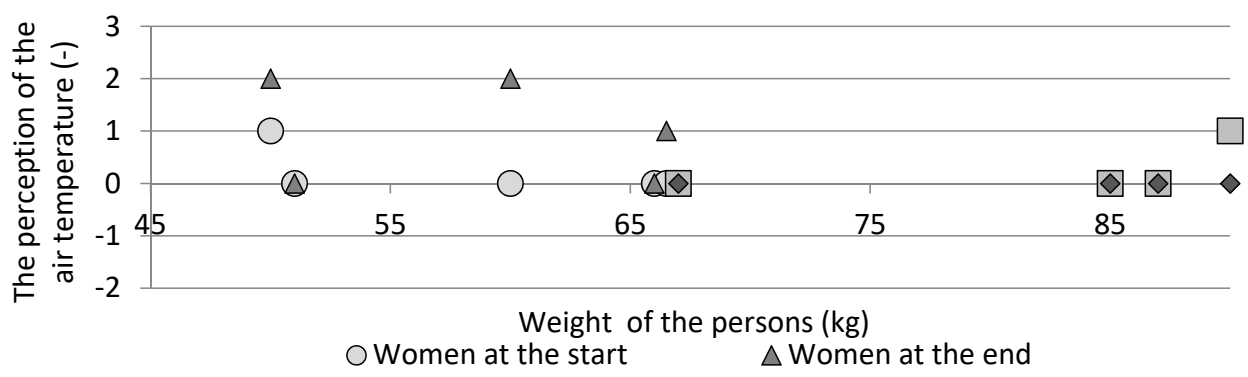

Figure 4. Perception of air temperature in office A.

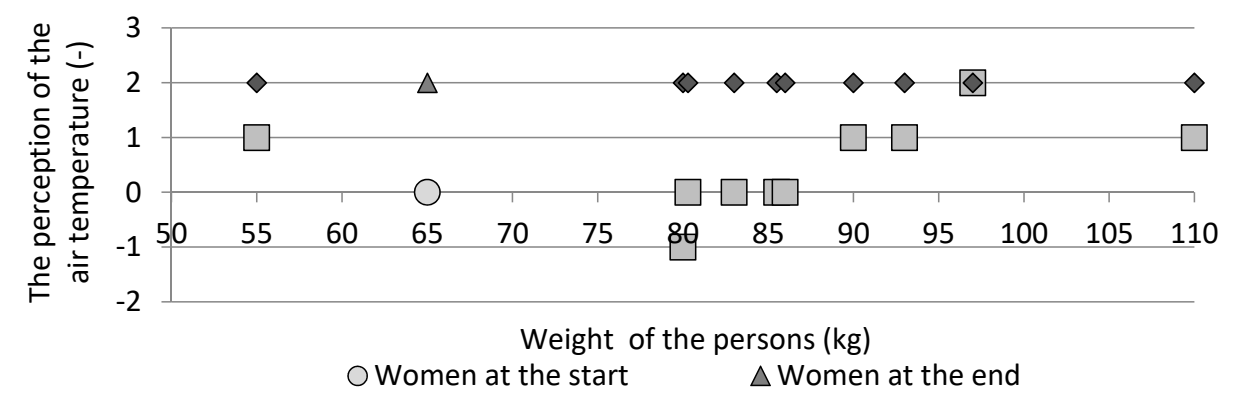

Figure 5. Perception of air temperature in office B.

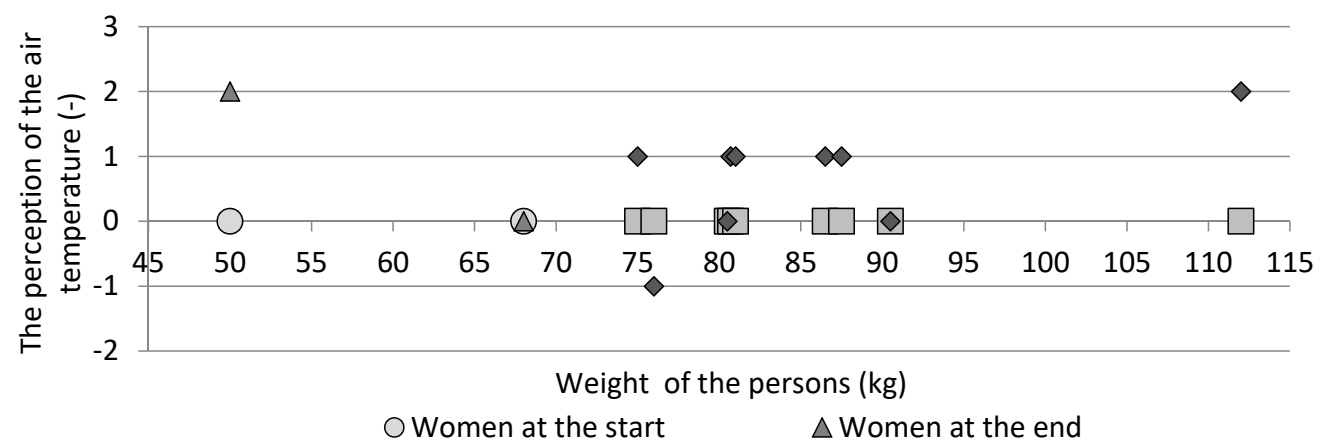

Figure 6. Perception of air temperature in office $\mathrm{C}$.

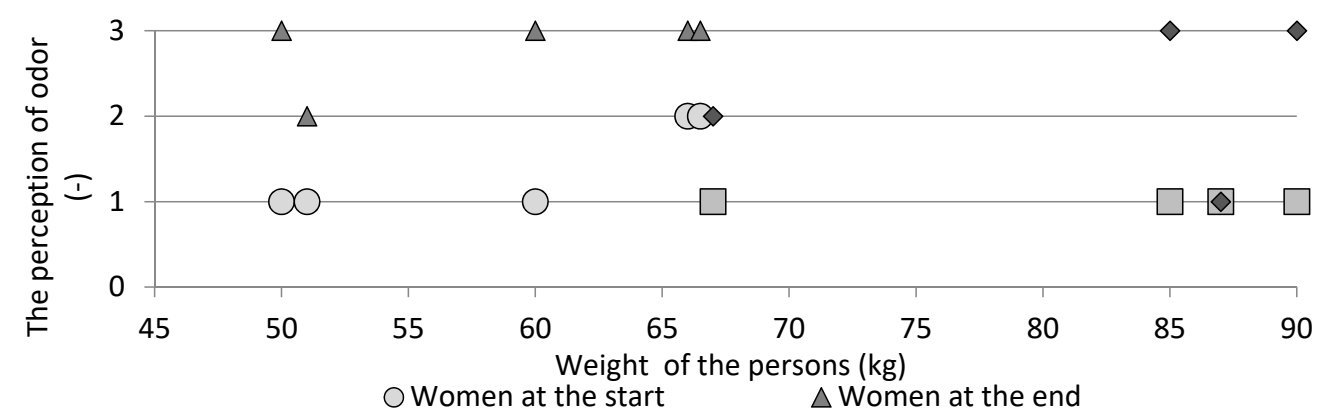

Figure 7. Perception of odor in office A.

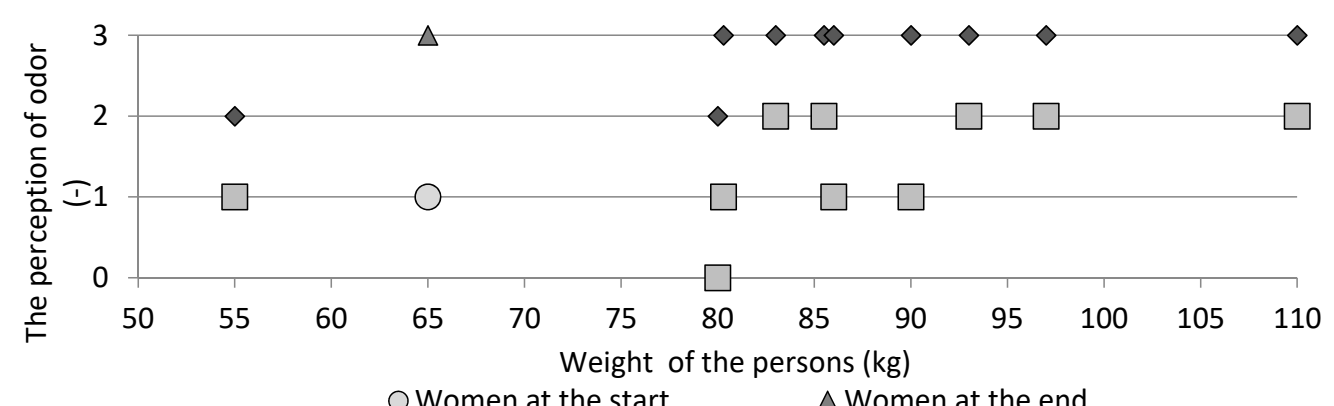

Figure 8. Perception of odor in office B. 


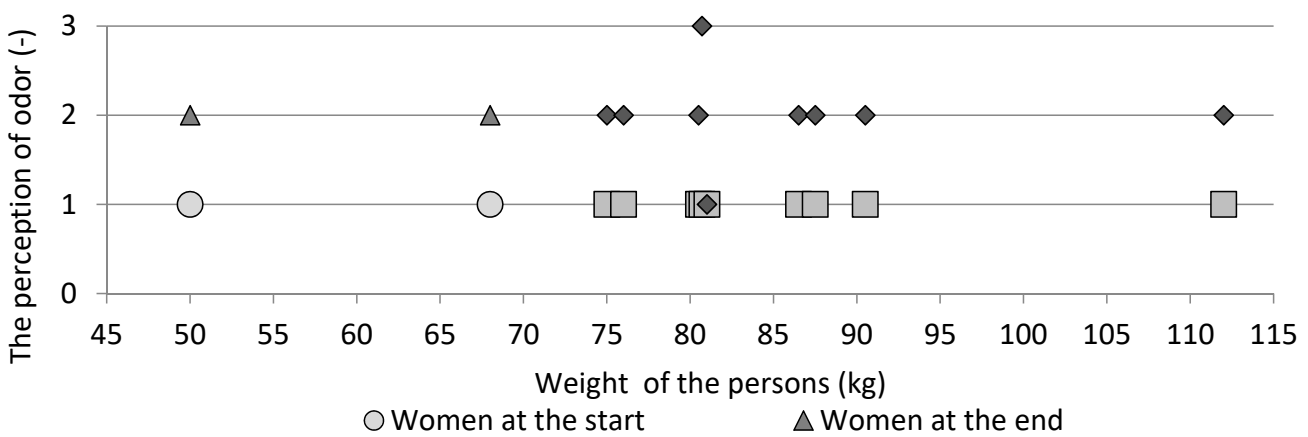

Figure 9. Perception of odor in office C.

\section{Conclusions}

When insufficient fresh air is supplied to a room, building users have to make more effort to perform their tasks and feel more fatigue. The performed experimental measurements and subjective evaluations showed the need to ensure the maximum $\mathrm{CO}_{2}$ concentration of $1000 \mathrm{ppm}$ in office rooms. When the $\mathrm{CO}_{2}$ concentration increases above this value, adverse effects begin to occur, reducing the performance of employees. Tired people need more time to regenerate than those who work in a room with a sufficient amount of fresh air. In the absence of fresh air in the room, with increasing weight, the pulse difference increases by approximately $20 \%$ compared to a room where sufficient fresh air is supplied. Research shows that even a small increase in $\mathrm{CO}_{2}$ concentration, in our case office A (1.162 ppm) in an enclosed ventilated space, causes undesirable discomfort. Lack of fresh air caused a slight change in heart rate in people, which may indicate attenuation or stunning. Subjective evaluation by questionnaires showed that women reacted more precisely to the change of indoor air temperature than men. Further, men with lower weight were more sensitive to changing air temperatures than men with a higher weight. It was similar in the perception of odors. On the basis of our experimental measurements, it is possible to conclude that the indoor air temperature and the carbon dioxide concentration in a room are suitable parameters for demand-controlled ventilation in order to guarantee indoor air quality.

Author Contributions: Conceptualization, P.K. and S.V.; methodology P.K.; validation, L'M. and F.D.; formal analysis, S.V.; investigation P.K.; writing draft paper, S.V. and L'.M.; review and editing, P.K and S.V.; supervision, F.D. and M.A. All authors have read and agreed to the published version of the manuscript.

Funding: This research received no external funding.

Acknowledgments: This study was financially supported by the Grant Agency of the Slovak Republic to support projects No. 1/0512/20 and 1/0697/17. This paper is also the result of the project implementation: University Science Park TECHNICOM for Innovation Applications Supported by Knowledge Technology, ITMS: 26220220182, supported by the Research and Development Operational Programme funded by the ERDF.

Conflicts of Interest: The authors declare no conflict of interest.

\section{References}

1. Shiram, S.; Rammamurthy, K.; Ramakrishnan, S. Effect of occupant-induced indoor $\mathrm{CO}_{2}$ concentration and bioeffluents on human physiology using a spirometric test. Build. Environ. 2019, 149, 58-67. [CrossRef]

2. Liu, Y.; Wang, Z.; Zhang, Z.; Hong, J.; Lin, B. Investigation on the indoor environment quality of health care facilities in China. Build. Environ. 2018, 141, 273-287. [CrossRef]

3. Mahyuddin, N.; Awbi, H. The spatial distribution of carbon dioxide in an environmental test chamber. Build. Environ. 2010, 45, 1993-2001. [CrossRef]

4. Hsu, Y.C.; Kung, P.Y.; Wu, T.N.; Shen, Y.H. Characterization of indoor-air bioaerosols in Southern Taiwan. Aerosol Air Qual. Res. 2012, 12, 651-661. [CrossRef]

5. Datta, A.; Suresh, R.; Gupta, A.; Singh, D.; Kulshrestha, P. Indoor air quality of non-residential urban buildings in Delhi, India. Int. J. Sustain. Built Environ. 2017, 6, 412-420. [CrossRef] 
6. Budaiová, Z.; Vilčeková, S. Assessing the effect of indoor environmental quality on productivity at office work. Sel. Sci. Pap. J. Civ. Eng. 2015, 10, 37-46. [CrossRef]

7. Mahyuddin, N.; Awbi, H. A review of $\mathrm{CO}_{2}$ measurement procedures in ventilation research. Int. J. Vent. 2012, 10, 353-370. [CrossRef]

8. Erdmann, C.A.; Apte, M.G. Mucous membrane and lower respiratory building related symptoms in relation to indoor carbon dioxide concentrations in the 100-building BASE dataset. Indoor Air. 2004, 14 (Suppl. 8), 127-134. [CrossRef]

9. Tsai, D.H.; Lin, J.S.; Chan, C.C. Office workers' sick building syndrome and indoor carbon dioxide concentrations. J. Occup. Environ. Hyg. 2012, 9, 345-351. [CrossRef]

10. WHO. Indoor Air Quality: Biological Contaminants: Report on a WHO Meeting, Ruatavaara, 29 Augusta 32 September 1988; European series. No. 31; WHO Regional Publications: Copenhagen, Denmark, 1988.

11. Zamani, M.E.; Jalaluding, J.; Shaharom, N. Indoor air quality and prevalence of sick building syndrome among office workers in two different offices in Selangor. Am. J. Appl. Sci. 2013, 10, 1140. [CrossRef]

12. Seppänen, O.A.; Fisk, W.J.; Mendell, M.J. Association of ventilation rates and $\mathrm{CO}_{2}$ concentrations with health and other responses in commercial and institutional buildings. Indoor Air. 1999, 9, 226-252. [CrossRef]

13. Vehviläinen, T.; Lindholm, H.; Rintamäki, H.; Pääkkönen, R.; Hirvonen, A.; Niemi, O.; Vinha, J. High indoor $\mathrm{CO}_{2}$ concentrations in an office environment increases the transcutaneous $\mathrm{CO}_{2}$ level and sleepiness during cognitive work. J. Occup. Environ. Hyg. 2016, 13, 19-29. [CrossRef] [PubMed]

14. Allen, J.G.; MacNaughton, P.; Cedeno-Laurent, J.G.; Cao, X.; Flanigan, S.; Vllarino, J.; Rueda, F.; Donnelly-McLay, D.; Spengler, J.D. Airplane pilot flight performance on 21 manoeuvres in a flight simulator under varying carbon dioxide concentrations. J. Expo. Sci. Environ. Epidemiol. 2018, 29, 457-468. [CrossRef]

15. Allen, J.G.; MacNaughton, P.; Satish, U.; Santanam, S.; Vallarino, J.; Spengler, J.D. Associations of cognitive function scores with carbon dioxide, ventilation, and volatile organic compound exposures in office workers: A controlled exposure study of green and conventional office environments. Environ. Health Perspect. 2016, 124, 805-812. [CrossRef] [PubMed]

16. Satish, U.; Mendell, M.J.; Shekhar, K.; Hotchi, T.; Sullivan, D.; Steufert, S.; Fisk, W.J. Is $\mathrm{CO}_{2}$ an indoor pollutant? Direct effects of low-to moderate $\mathrm{CO}_{2}$ concentrations on human decision-making performance. Environ. Health Perspect. 2012, 120, 1671-1677. [CrossRef] [PubMed]

17. Kajtár, L.; Herczeg, L. Influence of carbon-dioxide concentration on human well-being and intensity of mental work. QJ Hung. Meteorol. Serv. 2012, 116, 145-169.

18. Voznyak, O.; Sukholova, I.; Myroniuk, K. Research of device for air distribution with swirl and spread air jets at variable mode. East.-Eur. J. Enterp. Technol. 2015, 6, 15-23.

19. Tagliaro, C.; Ciaramella, A. Experiencing smart working: A case study on workplace change management in Italy. J. Corp. Real Estate 2016, 18, 194-208. [CrossRef]

20. Hua, Y.; Yang, E. Building spatial layout that supports healthier behavior of office workers: A new performance mandate for sustainable buildings. Work 2014, 49, 373-380. [CrossRef] [PubMed]

21. EN 15251:2007. Indoor environmental input parameters for design and assessment of energy performance of buildings addressing indoor air quality, thermal environment, lighting and acoustics.

(C) 2020 by the authors. Licensee MDPI, Basel, Switzerland. This article is an open access article distributed under the terms and conditions of the Creative Commons Attribution (CC BY) license (http://creativecommons.org/licenses/by/4.0/). 